DOI https://doi.org/10.18551/rjoas.2020-12.16

\title{
APPLICATION OF MYCORRHIZA BIOFERTILIZER AND INTERCROPPING WITH MUNGBEAN INCREASE GROWTH AND YIELD OF TWO SWEET POTATO VARIETIES
}

\author{
Wangiyana Wayan, Zubaidi Akhmad, Farida Nihla, Raehanayati \\ Faculty of Agriculture, University of Mataram, Lombok, Indonesia \\ *E-mail: w.wangiyana@unram.ac.id
}

\begin{abstract}
This study aimed to examine the effects of the application of a biofertilizer containing Arbuscular Mycorrhizal Fungi (AMF) and intercropping with mungbean plants on growth and tuber yield of two sweet potato varieties. The pot experiment was conducted in a plastic house, which was arranged according to Completely Randomized Design, testing three treatment factors, namely sweet potato varieties $(\mathrm{V} 1=$ Antin-3, V2 $=$ Sukuh), intercropping with mungbean $(I 0=$ without, $I 1=$ intercropping with mungbean), and application of mycorrhiza biofertilizer $(\mathrm{M} 0=$ without, $\mathrm{M} 1=$ with mycorrhiza). Data were analyzed with analysis of variance (ANOVA) using CoStat for Windows ver. 6.303. The results indicated that the three treatment factors had a significant effect on tuber weight per pot, and among the treatment factors, mycorrhiza biofertilizer had the most significant effect. However, there were two-way interaction effects on some observation variables, and three-way interaction effects on the total length of branches and tuber weight per pot, and it was found that the highest tuber yield was on the sweet potato plants supplied mycorrhiza biofertilizer and intercropped with mungbean, with an average tuber weight of $301.8 \mathrm{~g} / \mathrm{pot}$ (or $30.18 \mathrm{ton} / \mathrm{ha}$ ) on Antin-3 variety or $287.0 \mathrm{~g} /$ pot (or 28.70 ton/ha) on Sukuh variety, and the lowest tuber yield was on the monocropped sweet potato plants without application of mycorrhiza biofertilizer, with an average tuber weight of $55.0 \mathrm{~g} /$ pot (or $5.50 \mathrm{ton} / \mathrm{ha}$ ) on Antin-3 variety or $122.10 \mathrm{~g} / \mathrm{pot}$ (or $12.21 \mathrm{ton} / \mathrm{ha}$ ) on Sukuh variety.
\end{abstract}

\section{KEY WORDS}

Additive intercropping, mungbean, sweet potato, mycorrhiza, biofertilizer.

Sweet potato (Ipomoea batatas (L.) Lam.) is one of the food crops that produce carbohydrates for food. It globally ranks seventh in the world crop statistics, right after cassava. The tubers are rich in carbohydrates and vitamin A and the leaves are rich in protein. Sweet potatoes can produce more edible energy per hectare and per day than wheat, rice or cassava. Sweet potatoes have various uses ranging from its function as food by consuming the fleshy tubers or leaves or for use as animal feed, or for processing it to produce flour, noodles, natural dyes, alcohol, and others. The underground storage organs of sweet potato plants are storage roots, like cassava plants [1]. From its nutritional value, in addition to its high carbohydrate content (around 32\%), sweet potato fleshy tuber, especially from yellow sweet potato is high in vitamin A, calcium and phosphorus, as well as Niacin, vitamins $\mathrm{B} 1, \mathrm{~B} 2$, and vitamin $\mathrm{C}$ [2].

In addition to its use as a food source because of its high carbohydrate content of the tubers, sweet potato plants also have high health values, both for humans and for livestock, which made sweet potato plants to be classified as medicinal crops [3]. Sweet potato plants are also known as functional foodstuffs because they can be used for the prevention and treatment of chronic diseases through their ability to function as an antioxidant, antiinflammatory, immunomodulatory, anticancer/antitumour, antimicrobial and antiulcer [4]. In Indonesia, the sweet potato plant varieties, which produce purple tuber flesh, are known to contain lots of anthocyanins and polyphenols which can function as antioxidants and food coloring, for example the Antin-1 variety. The leaves of this sweet potato variety also contain many types of anthocyanins [5], [6]. Ji et al. [7] also reported that the fleshy tuber of sweet potato is high in anthocyanin content, especially in the purple fleshed sweet potato, which 
contains much higher concentration of anthocyanin and antioxidant activities than in the red and yellow fleshed sweet potato. Therefore, consuming sweet potatoes is not just for food but also for maintaining body health.

The demand for domestic sweet potatoes continues to increase, either for food, industry or animal feed, while the productivity achieved by farmers in Indonesia is still low, which is around $40 \%$ of the genetic potential [8]. Therefore, it is necessary to continue to strive for innovative researches for assembling production technologies and disseminating them to the farmers. Some research results show that the productivity of several sweet potato varieties can be increased by application of mycorrhizal biofertilizer (AMF) and liming to increase soil $\mathrm{pH}$, especially in cultivation of sweet potato following paddy rice [9]. The results of a study in Cuba showed that AMF inoculation on two sweet potato clones ('INIVIT B2-2005' \& 'CEMSA 78-354') significantly increased tuber yield and efficiency of phosphate fertilizer uses, especially at low $P$ doses [10].

In addition, the application of phosphate solubilizing bacteria (BPF) was also reported to have a positive and significant effect in increasing tuber yield of sweet potato and the efficiency of P uptake [11]. From the significant effect of AMF and BPF application, it means that the $\mathrm{P}$ nutrient is very crucial for the growth and formation of tuber yields in sweet potato plants. However, because flooded system of rice cultivation depletes $\mathrm{N}$ nutrient in paddy fields, both through uptake by rice plants and volatilization and infiltration [12], [13], [14], the effect of $\mathrm{N}$ fertilization is often very significant in increasing the yield of post-rice sweet potato [8]. Several studies have also shown that intercropping of non-legume with legume crops can increase $\mathrm{N}$ uptake of non-legume plants because there is a transfer of $\mathrm{N}$ from legume to nonlegume rhizosphere [15], [16], [17], and the rate of $N$ transfer will increase if AMF infection of both crops is involved [18].

Considering that the availability of $\mathrm{N}$ fertilizers is often scarce outside the rice planting season, it is necessary to find production technologies to increase yield of sweet potatoes through the application of AMF and intercropping with legume crops. This study aimed to examine the effects of the application of a biofertilizer containing Arbuscular Mycorrhizal Fungi (AMF) and intercropping with mungbean plants on growth and tuber yield of two varieties of sweet potatoes.

\section{MATERIALS AND METHODS OF RESEARCH}

Design of the experiment. Because it was difficult to get large number of cuttings of sweet potato seedlings with defined names of varieties, the experiment was carried out by growing sweet potatoes in pots in a plastic house, located in a rice field in Dasan Tebu village, West Lombok, Indonesia, from June to November 2020. The experiment was arranged according to the Completely Randomized Design, with three replications and three treatment factors arranged factorially, namely sweet potato varieties (V1= Antin-3, V2= Sukuh), intercropping with mungbean ( $\mathrm{IO}=$ without mungbean (or monocrop), $\mathrm{I} 1=$ intercropping with mungbean), and application of mycorrhiza biofertilizer ( $\mathrm{M} 0=$ without, $\mathrm{M} 1=$ with mycorrhiza).

Implementation of the experiment. The plastic pots used in the experiment had a capacity of 12 liters with an upper opening diameter of $28 \mathrm{~cm}$, which were filled with 9.8 $\mathrm{kg} /$ pot of entisol paddy soil which has been air-dried and sieved using $2 \mathrm{~mm}$ sieving mesh. The pot was punctured from two sides at the bottom of the pot to make 2 holes in the opposite direction for function as drainage holes. The sweet potato cuttings were supplied by the Balitkabi Research Institute in Malang, East Java. On the arrival, the cuttings were grown in polybags of $7.5 \times 7.5 \mathrm{~cm}$ base for a week until they produced buds, and after one week, only the cuttings that produced new buds were transplanted into the experimental pots without breaking the soil in the polybags. For the pots with mycorrhiza application (M1), the biofertilizer "RhizoPlex" containing several species of AMF was applied at the bottom of the planting hole of the sweet potato, with the recommended dose of 5 gram per plant (per pot). For the pots of intercropping sweet potatoes with mungbean, the seeds of mungbean ("Vima4 " variety) were dibbled one week after transplanting of sweet potato cuttings with a distance 
of $8 \mathrm{~cm}$ between the two plant bases, and the planting holes of both crops were positioned at $4 \mathrm{~cm}$ distance from the center of the soil surface in the pot.

NPK fertilization was done by dibbling Phonska fertilizer (NPK 15-15-15) at the age of one week after transplanting at a dose of $300 \mathrm{~kg} / \mathrm{ha}(3.0 \mathrm{~g} / \mathrm{plant}$, assuming plant spacing of $40 \times 25 \mathrm{~cm})$ for sweet potatoes, and $200 \mathrm{~kg} / \mathrm{ha}(1.0 \mathrm{~g} / \mathrm{plant})$ for mungbean plants one week after seeding, by dibbling the fertilizer at $7 \mathrm{~cm}$ depth and $7 \mathrm{~cm}$ from each plant base, and in the intercropping pots, fertilizer holes were made at the longest distance from the center of the soil surface. Watering was done every day by watering the soil in the pot according to the dryness of the soil in the pot with increasing amount of water as the plants older. Final harvest of mungbean was done at 11 weeks after seeding, while harvest of sweet potato vines and leaves and tubers was done at the age of 5 months.

Observation variables and data analysis. Growth variables observed were number and total length of branches, number of leaves on the branches per pot at 12 weeks after transplanting, and fresh weights of stover (vines and leaves) and tubers per pot at harvest. Data were analyzed using analysis of variance (ANOVA) and Tukey's HSD at $5 \%$ level of significance, using CoStat for Windows ver. 6.303. Correlation analysis was also done between specific observation variables using Minitab for Windows Rel. 13.0

\section{RESULTS AND DISCUSSION}

The ANOVA results, summarized in Table 1, show that among the treatment factors tested, application of mycorrhiza biofertilizer resulted in the most significant effects, followed by intercropping, but the varieties of sweet potatoes were different only in total length of branches per pot. However, there were three-way and two-way interaction effects on several observation variables, and the observation variables showing the most interaction was the fresh weight of tuber at harvest to which the interaction effects of $V^{*} \mid, I^{*} M$ and $V^{*} I^{*} M$ were significant. The three-way interaction was also significant on the total length of branches per pot. The two-way interaction of $\mathrm{V}^{*} \mathrm{I}$ was also significant on number of branches and total leaves on the branches, and $I^{*} \mathrm{M}$ interaction was also significant on total length of branches and total leaves on the branches, while the $\mathrm{V}^{*} \mathrm{M}$ interaction was not significant on all observation variables.

Table 1 - Summary of the ANOVA results of the main and interaction effects for all observation variables of the sweet potato

\begin{tabular}{|c|c|c|c|c|c|c|c|}
\hline \multirow{2}{*}{ Observation variables } & \multicolumn{3}{|l|}{ Main effects } & \multicolumn{4}{|c|}{ Interaction effects } \\
\hline & Varieties (V) & Intercrop-ping (I) & Mycorrhiza (M) & $\mathrm{V}^{*} \mathrm{I}$ & $\mathrm{V}^{*} \mathrm{M}$ & $I^{\star} \mathrm{M}$ & $\mathrm{V}^{*} \mathrm{I}^{*} \mathrm{M}$ \\
\hline Number of branches per pot & ns & ns & ns & * & ns & ns & $\mathrm{ns}^{11}$ \\
\hline Total length of branches per pot & ** & ** & *** & ns & ns & *** & * \\
\hline Total number of branch leaves per pot & ns & ns & * & * & ns & * & ns \\
\hline Stover weight (vines \& leaves) per pot & ns & *** & ** & ns & ns & ns & ns \\
\hline Tuber weight per pot & ns & $* * *$ & $\star \star * *$ & ** & ns & $\star * * *$ & * \\
\hline
\end{tabular}

Note: ${ }^{1)} n s=$ non-significant; *, ${ }^{* *}$ and ${ }^{* * *}=$ significant at $p$-value $<0.05,<0.01$ and $<0.001$, respectively.

Table 2 - Mean values of branch number, total branch length, branch leaf number, fresh weight of vines and leaves, and tuber yield of sweet potato per pot for each treatment

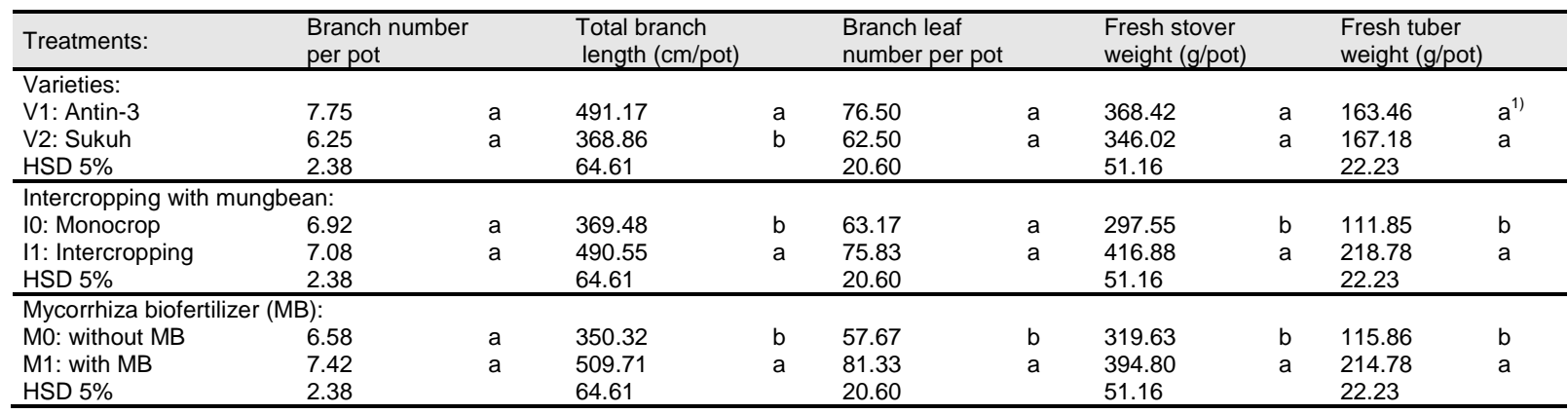

Note: ${ }^{1)}$ Mean values in each column of a variable followed by the same letters are not significantly different between levels of a treatment factor (main effects). 
Based on the means test summarized in Table 2, application of mycorrhiza biofertilizer actually increased mean values of all observation variables although it was not significant on number of branches per pot. In relation to its effect yield, application of mycorrhiza biofertilizer almost doubled the fresh weight of tubers per pot (85.4\% increases). Many have also reported that AMF application on sweet potato significantly increased tuber yield, such as those reported by Laxminarayana et al. [9] and Cuellar et al. [10]. In addition, application of phosphate solubilizing bacteria, which are capable of increasing the availability of phosphates in the rhizosphere was also reported to increase tuber yield of sweet potatoes as well as increasing efficiency of P-uptake by sweet potato plants [11]. These indicate that the sufficient availability of phosphates is very important for tuber yield of sweet potatoes.

There was also an average of $41.02 \%$ increase in total number of branch leaves per pot due to application of the mycorrhiza biofertilizer, and this increase was significant (Table 2). This could also mean that the photosynthetic capacity of sweet potato is increased by application of the mycorrhiza biofertilizer at transplanting, which resulted in significant increase in tuber yield per pot. There was also a significant positive correlation between total number of branch leaves and tuber weight per pot, with a correlation $(r)$ coefficient of +0.624 , with a $p$-value $<0.01$ (Table 3 ).

Table 3 - Multiple correlation coefficients $(r)$ between selected observation variables

\begin{tabular}{lllllllll}
\hline \multirow{2}{*}{ Observation variables } & \multicolumn{2}{l}{ Branch number } & \multicolumn{2}{l}{ Branch length } & \multicolumn{2}{l}{ Tuber weight } & \multicolumn{2}{l}{ Stover weight } \\
\cline { 2 - 9 } & $\mathrm{r}$ value & $\mathrm{p}$-value & $\mathrm{r}$ value & $\mathrm{p}$-value & $\mathrm{r}$ value & $\mathrm{p}$-value & $\mathrm{r}$ value & $\mathrm{p}$-value \\
\hline Branch length & 0.570 & 0.004 & & & & & & \\
Tuber weigth & 0.424 & 0.039 & 0.751 & 0.000 & & & & \\
Stover weight & 0.331 & 0.114 & 0.529 & 0.008 & 0.776 & 0.000 & & 0.020 \\
Branch leaf number & 0.720 & 0.000 & 0.706 & 0.000 & 0.624 & 0.001 & 0.471 & 0.020 \\
\hline
\end{tabular}

Intercropping sweet potato with mungbean was also capable of increasing mean values of all observation variables, although the increase was significant only on total length of branches, total vines and leaves at harvest and tuber weight per pot (Table 2). Although the increase in total number of branch leaves was not significant due to intercropping sweet potato with mungbean many have reported significant transfer of fixed $\mathrm{N}$ from legume to nonlegume plants in an intercropping system [16], [17], and the amount of $\mathrm{N}$ transfer was found higher as the planting distances between both crops was closer in the case of intercropping sorghum with soybean [15]. Nitrogen and chlorophyll contents in rice leaves were increased by intercropping with peanut [16]. Wangiyana et al. [19] also reported that leaves of waxy maize were greener under intercropping with mungbean compared with those of monocropped waxy maize. These could mean that intercropping with mungbean could increase photosynthetic capacity of the leaves that might have contributed more photosynthate to result in higher weight of fresh tubers in the sweet potato intercropped with mungbean compared with those grown in monocrop (Table 2).

However, there were also two-way and three-way interaction effects on some observation variables (Table 1). Based on the interaction effects between varieties and intercropping, it can be seen from Fig. 1 to Fig. 1 and Fig. 2 that intercropping with mungbean significantly increased branch number and branch leaf number per pot in Antin-3 variety but not in Sukuh variety, in which branch number and leaves tend to be decreased by intercropping. However, tuber weight per pot was significantly increased by intercropping in both varieties (Fig. 3). In relation to application of mycorrhiza biofertilizer, both intercropping with mungbean and mycorrhiza significantly increased tuber weight per pot, and the increase was more significant in sweet potato plants both intercropped with mungbean and supplied with mycorrhiza biofertilizer (Fig. 6). Branch length per pot was also increased by application of mycorrhiza biofertilizer but only on sweet potato plants intercropped with mungbean, while without intercropping, mycorrhiza did not increase branch length per pot (Fig. 5). This trend was also similar on total number of branch leaves (Fig. 4), in which the average branch leaf number was significantly increased by application of mycorrhiza biofertilizer but only on sweet potato plants that were intercropped with mungbean. These become clearer by looking 
at the three-way interaction effects on branch length per pot in Fig. 7, in which total branch length was increased by application of mycorrhiza biofertilizer but only on sweet potato plants that were intercropped with mungbean, and between the varieties, it seems that Antin3 variety was much more responsive than Sukuh variety.

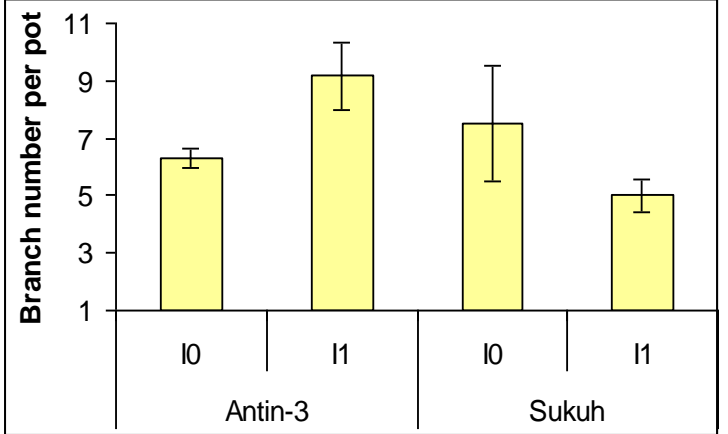

Figure 1 - Average (Mean $\pm \mathrm{SE}$ ) branch number per pot as affected by interaction between varieties and intercropping with mungbean

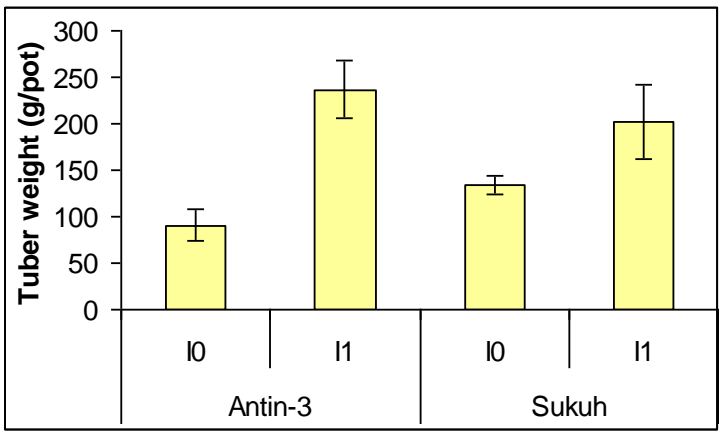

Figure 3 - Average (Mean $\pm \mathrm{SE}$ ) tuber weight $(\mathrm{g} / \mathrm{pot}$ ) as affected by interaction between varieties and intercropping with mungbean

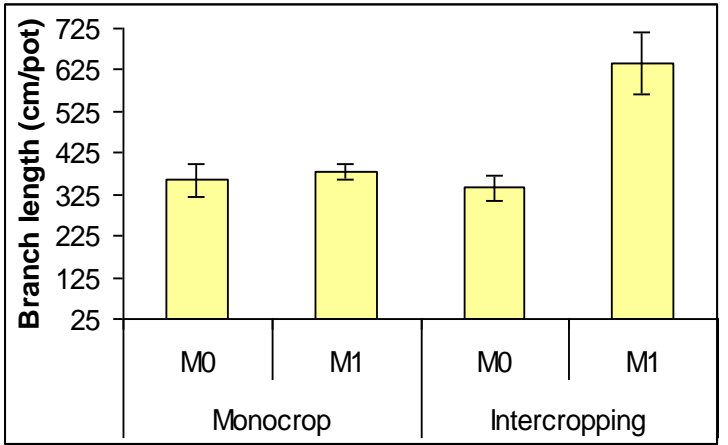

Figure 5 - Average (Mean \pm SE) branch length per pot as affected by interaction between mycorrhiza and intercropping with mungbean

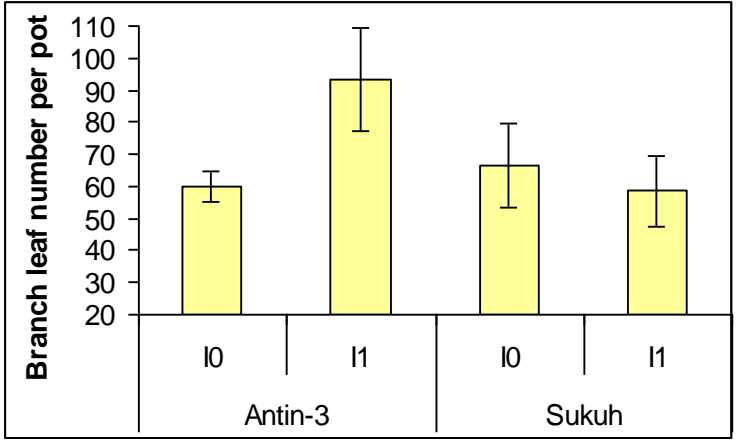

Figure 2 - Average (Mean \pm SE) branch leaf number per pot as affected by interaction between varieties and intercropping with mungbean

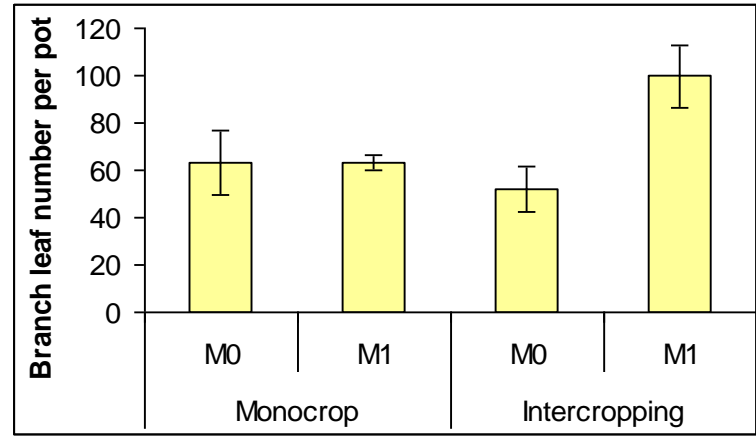

Figure 4 - Average (Mean \pm SE) branch leaf number per pot as affected by interaction between mycorrhiza and intercropping with mungbean

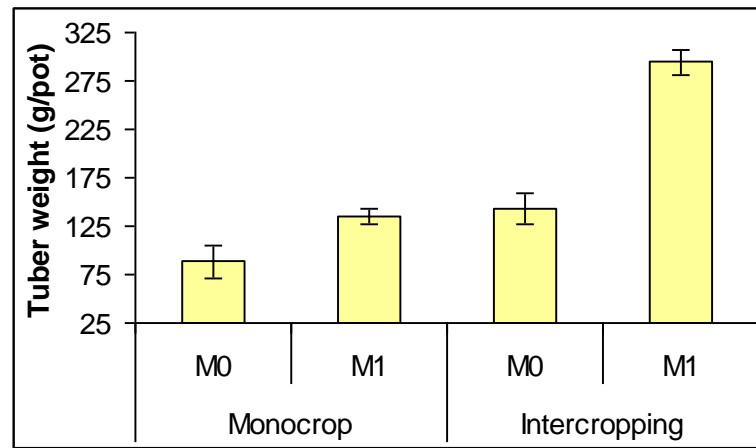

Figure 6 - Average (Mean $\pm \mathrm{SE}$ ) tuber weight $(\mathrm{g} / \mathrm{pot}$ ) as affected by interaction between mycorrhiza and intercropping with mungbean

The patterns of the three-way interaction effects on the tuber weight per pot in Fig. 8 could reveal the different responses of both varieties to the application of mycorrhiza biofertilizer and intercropping with mungbean. "Antin-3", a purple fleshed sweet potato variety, significantly responded to both mycorrhiza and intercropping, in which application of mycorrhiza biofertilizer significantly increased tuber weight, either under monocropped or intercropped with mungbean, although the increase was more significant under intercropping. "Sukuh", a white fleshed sweet potato variety, on the other hand, only 
increased its tuber weight per pot due to mycorrhiza when intercropped with mungbean or due to intercropping when supplied with mycorrhiza biofertilizer.

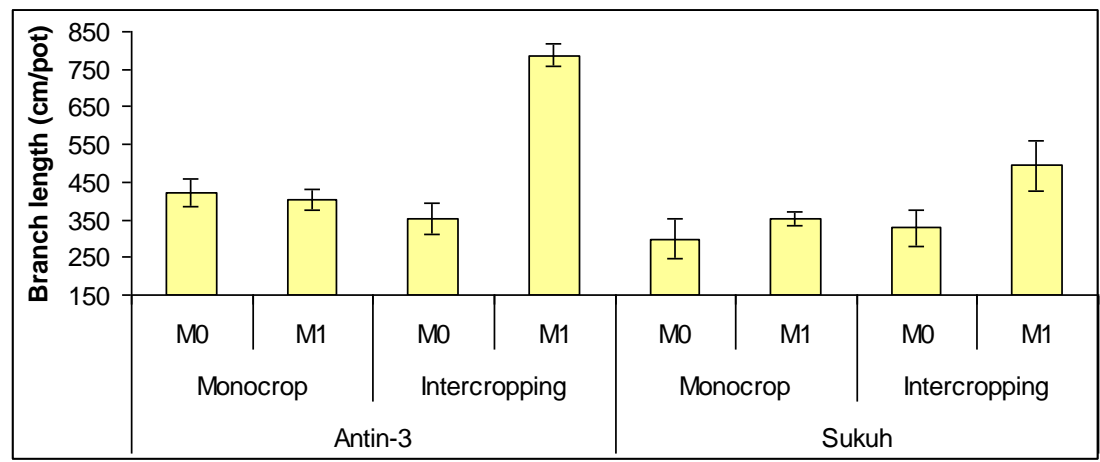

Figure 7 - Average (Mean \pm SE) total branch length per pot as affected by three-way interaction between varieties, mycorrhiza and intercropping with mungbean

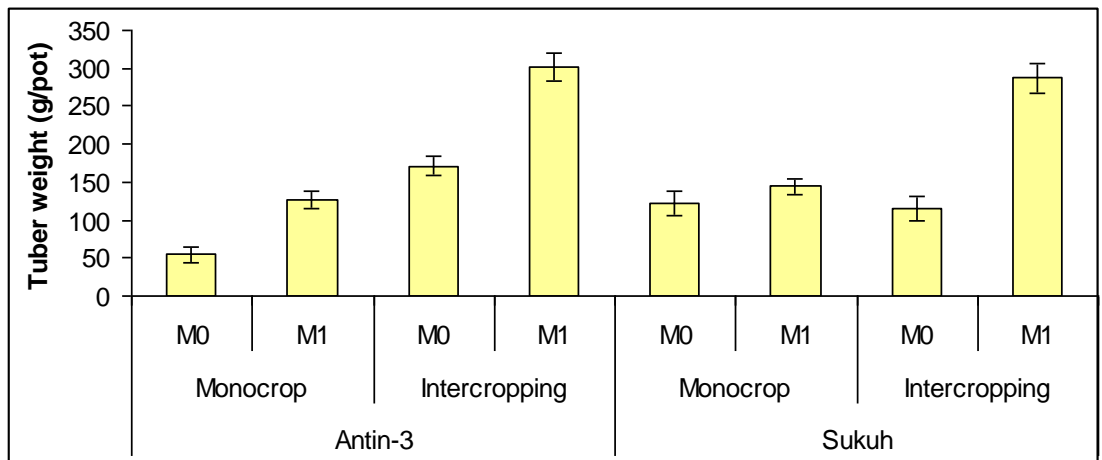

Figure 8 - Average (Mean $\pm \mathrm{SE}$ ) tuber weight $(\mathrm{g} / \mathrm{pot}$ ) as affected by three-way interaction between varieties, mycorrhiza and intercropping with mungbean

This means that Sukuh variety will significantly increase it tuber weight when both intercropped with mungbean and supplied with mycorrhiza biofertilizer but Antin-3 variety will be able to increase its tuber weight either intercropped with mungbean or supplied with mycorrhiza biofertilizer. However, both varieties of sweet potatoes showed synergistic effects of mycorrhiza and intercropping with mungbean on tuber weight per pot (Fig. 8). Legume crops such as soybean and mungbean are capable of establishing tripartite symbiosis with Rhizobium bacteria and AMF [20], [21], [22]. In soybean, symbiosis with Bradyrhizobium japonicum and the AMF species Glomus clarum significantly increased nodule number and weight, $\mathrm{N}$ concentration and $\mathrm{N}$ content per plant, and the amount of nitrogen fixed by soybean plants when compared to symbiosis only with $B$. japonicum alone [20]. Wangiyana and Farida [23] also reported that application of Rhizobium inoculant together with AMF biofertilizer resulted in significantly higher soybean grain yield and grain number per clump compared with application of Rhizobium only or NPK fertilizer. In mungbean, inoculation with both Rhizobium and AMF resulted in significantly higher grain yield compared to inoculation with Rhizobium only or AMF only [21]. Inoculation with mixed bacterial inoculants ( $B$. japonicum MN-S, TAL-102 and Agrobacterium sp.) and AMF not only increased grain yield of mungbean compared to inoculation with mixed bacterial inoculants or AMF only, but also significantly increased nodule number and \% $\mathrm{N}$ content in the grains [22].

In an intercropping system of legume and non-legume crops, significant transfer of fixed $\mathrm{N}$ from legume to non-legume crops has been reported, for example by Chu et al. [16] in intercropping rice with peanut and by Fujita et al. [15] in intercropping sorghum with soybean, and the amount of $\mathrm{N}$ transferred was increased by the involvement of $A M F$ infecting root systems of both crops [18], especially under closer planting distance between both crops. Inal et al. [17] also reported significantly higher chlorophyll, $\mathrm{P}$ and $\mathrm{K}$ contents in 
maize plants intercropped with peanut than in monocropped maize. In this study, the planting distance between sweet potato and mungbean was only $8 \mathrm{~cm}$, which was much closer than the closest planting distance $(12.5 \mathrm{~cm})$ resulting in the highest $\mathrm{N}$ transfer from soybean to sorghum reported by Fujita et al. [15]. Application of mycorrhiza biofertilizer in the planting holes of red rice plants intercropped with several varieties of mungbean was also reported to significantly increase panicle number, filled grain number, percentage of filled grain number and grain yield of red rice plants compared with those intercropped with mungbean but without application of mycorrhiza biofertilizer [24]. These indicate the beneficial effects of AMF, especially for non-legume crops in intercropping with legume crops. Therefore, it was highly possible that application of mycorrhiza biofertilizer and intercropping with mungbean significantly increased total number of leaves on the branches and tuber yield of sweet potato per pot in this study.

\section{CONCLUSION}

It can be concluded that application of mycorrhiza biofertilizer and intercropping with mungbean significantly increased growth and tuber weight of sweet potato per pot, and based on the three-way interaction effects on tuber weight per pot, it was found that the highest tuber yield was on the sweet potato plants supplied mycorrhiza biofertilizer and intercropped with mungbean, with an average tuber weight of $301.8 \mathrm{~g} / \mathrm{pot}$ (or $30.18 \mathrm{ton} / \mathrm{ha}$ ) on Antin-3 variety or $287.0 \mathrm{~g} /$ pot (or $28.70 \mathrm{ton} / \mathrm{ha}$ ) on Sukuh variety, and the lowest tuber yield was on the monocropped sweet potato plants without application of mycorrhiza biofertilizer, with an average tuber weight of $55.0 \mathrm{~g} /$ pot (or 5.50 ton/ha) on Antin-3 variety or $122.10 \mathrm{~g} /$ pot (or $12.21 \mathrm{ton} / \mathrm{ha}$ ) on Sukuh variety.

\section{ACKNOWLEDGEMENTS}

Through this article, the research team would like to thank the Rector, the Chairperson of the Institute of Research and Community Service, and the Dean of the Faculty of Agriculture, University of Mataram for the "PNBP" research fund provided, with the contract, No: 2727/UN18.L1/PP/2020.

\section{REFERENCES}

1. Lebot, V., 2009. Tropical Root and Tuber Crops: Cassava, Sweet Potato, Yams, and Aroids. CAB International, Oxfordshire, UK. Kim, J. et al., 2002. Ultrafast Dephasing of Photoexcited Polarons in Primary Doped Polyaniline. Journal of Physical Chemistry, 106: 1286-12873.

2. Utomo, J.S., and Ginting, E. 2012. Komposisi kimia. In: J. Wargiono dan Hermanto (Eds), Ubi Jalar: Inovasi Teknologi dan Prospek Pengembangan. Balitkabi, Malang. Pp. 271301.

3. Mohanraj, R., and Sivasankar, S. 2014. Sweet Potato (Ipomoea batatas [L.] Lam) - A Valuable Medicinal Food: A Review. J Med Food 17(7), 733-741.

4. Ayeleso, T.B., Ramachela, K., and Mukwevho, E. 2016. A review of therapeutic potentials of sweet potato: Pharmacological activities and influence of the cultivar. Tropical Journal of Pharmaceutical Research, 15(12), 2751-2761.

5. Jusuf, M., Rahayuningsih, S.A., Wahyuni, T.S., and Ginting, E. 2013. Antin 1: Varietas Unggul Ubijalar Mengandung Antosianin Yang Cocok Untuk Bahan Baku Kripik. In: N. Saleh et al. (Eds), Prosiding Seminar Nasional Hasil Penelitian Tanaman Aneka Kacang dan Umbi, Malang, 22 Mei 2013. Balitkabi, Malang.

6. Ginting, E., Utomo, J.S., and Richana, N. 2012. Keunggulan fungsional ubijalar dari aspek kesehatan. In: J. Wargiono dan Hermanto (Eds), Ubi Jalar: Inovasi Teknologi dan Prospek Pengembangan. Balitkabi, Malang. Pp. 302-316. 
7. Ji, H., Zhang, H.X., Li, H.T. and Li, Y.C. 2015. Analysis on the Nutrition Composition and Antioxidant Activity of Different Types of Sweet Potato Cultivars. Food and Nutrition Sciences, 6: 161-167. http://dx.doi.org/10.4236/fns.2015.61017.

8. Wargiono, J., Wahyuni, T.S., and Manshuri, A.G. 2012. Pengembangan areal pertanaman dan sistem produksi. In: J. Wargiono dan Hermanto (Eds), Ubi Jalar: Inovasi Teknologi dan Prospek Pengembangan. Balitkabi, Malang. Pp. 117-142.

9. Laxminarayana, K. et al, 2015. Long-Term Effect of Lime, Mycorrhiza, and Inorganic and Organic Sources on Soil Fertility, Yield, and Proximate Composition of Sweet Potato in Alfisols of Eastern India. Comm. Soil Sci. Plant Analysis, 46: 605 - 618.

10. Cuéllar, A.E., Martinez, L.R., Espinosa, R.R., and Cuéllar, E.E. 2019. The Inoculation with an Effecient AMF Strain Decreases the Phosphoric Fertilizer Requirements in Ipomea batata (L) Lam in Dry Period. J. Chem. Environ. Biol. Engineering, 3(2): 13-18.

11. Sukmasari, M.D., Waluyo, B., and Karuniawan, A. 2016. Pengaruh Bakteri Pelarut Fosfat terhadap Efisiensi Pemupukan P, Serapan P dan Hasil Ubi Jalar. In: A.A. Rahmianna et al. (Eds), Inovasi Teknologi Lahan Suboptimal untuk Pengembangan Tanaman Aneka Kacang dan Umbi Mendukung Pencapaian Kedaulatan Pangan Malang, Prosiding Seminar Nasional Hasil Penelitian Tanaman Aneka Kacang dan Umbi, 25 Mei 2016. Balitkabi, Malang.

12. De Datta, S.K. et al, 1991. Direct Measurement of Ammonia and Denitrification Fluxes from Urea Applied to Rice. Soil Sci. Soc. Am. J., 55: 543-548.

13. Buresh, R.J., De Datta, S.K., Samson, M.I., Phongpan, S., Snitwongse, P., Fagi, A.M. and Tejasarwana, R. 1991. Dinitrogen and Nitrous Oxide Flux from Urea Basally Applied to Puddled Rice Soils. Soil Sci. Soc. Am. J., 55: 268-273.

14. Choudhury et al, 2005. Nitrogen Fertilizer Losses from Rice Soils and Control of Environmental Pollution Problems. Comm. Soil Sc. and Plant Analysis, 36: 1625-1639.

15. Fujita, K., Ogata, S., Matsumoto, K., Masuda, T., Ofosu-Budu, G.K., and Kuwata, K. 1990. Nitrogen Transfer and Dry Matter Production in Soybean and Sorghum Mixed Cropping System at Different Population Density. Soil Sci. Plant Nutr., 36(2): 233-241.

16. Chu, G.X., Shen, Q.R. and Cao, J.L. 2004. Nitrogen fixation and N transfer from peanut to rice cultivated in aerobic soil in an intercropping system and its effect on soil $\mathrm{N}$ fertility. Plant and Soil, 263: 17-27.

17. Inal, A. et al, 2007. Peanut/maize intercropping induced changes in rhizosphere and nutrient concentrations in shoots. Plant Physiology and Biochemistry, 45: 350-356.

18. Bethlenfalvay G.J., Reyes-Solis, M.G., Camel, S.B. and Eerrera-Cerrato, R. 1991. Nutrient transfer between the root zones of soybean and maize plants connected by a common mycorrhizal mycelium. Physiologia Plantarum, 82: 423-432.

19. Wangiyana, W., Irwinsyah, L.R., Parawinata, and Kisman. 2020. Additive Intercropping with Legume Crops Increases Waxy Maize Yield on Vertisol Riceland in Lombok, Indonesia. Russian Journal of Agricultural and Socio-Economic Sciences, 102(6): 57-64.

20. Antunes, P.M., de Varennes, A., Rajcan, I., and Goss, M.J. 2006. Accumulation of specific flavonoids in soybean (Glycine max (L.) Merr.) as a function of the early tripartite symbiosis with arbuscular mycorrhizal fungi and Bradyrhizobium japonicum (Kirchner) Jordan. Soil Biology \& Biochemistry, 38: 1234-1242.

21. Yasmeen, T., Hameed, S., Tariq, M., and Ali, S. 2012a. Significance of arbuscular mycorrhizal and bacterial symbionts in a tripartite association with Vigna radiata. Acta Physiol Plant, DOI: 10.1007/s11738-012-0950-x.

22. Yasmeen, T., Hameed, S., Tariq, M., 2012b. Vigna radiata root associated mycorrhizae and their helping bacteria for improving crop productivity. Pak. J. Bot., 44(1): 87-94.

23. Wangiyana W. and Farida N. 2019. Application bio-fertilizers to increase yields of zerotillage soybean of two varieties under different planting distances in dry season on vertisol land of Central Lombok, Indonesia. AIP Conference Proceedings 2199, 040009 (2019); https://doi.org/10.1063/1.5141296.

24. Wangiyana, W., Aryana, I.G.P.M., Gunartha, I.G.E., and Dulur, N.W.D. 2018. Pengaruh Inokulasi Mikoriza terhadap Komponen Hasil Padi Sistem Pengairan Aerobik yang Ditumpangsarikan dengan Kacang Hijau. AgriTECH, 38(3): 289-294. 